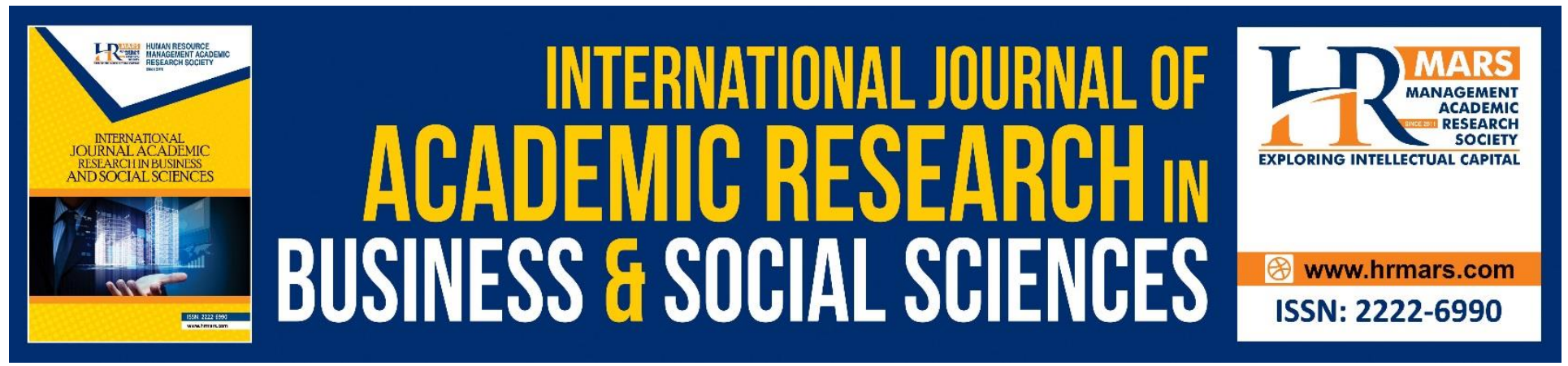

\title{
The Conceptual Framework between Hygiene and Motivational Factors towards Employees Performance in Joint Force Headquarters of Malaysia Armed Forces
}

Khairatun Hisan Idris Shazali, Nor Zarina Abu, Noor Liyana Ruslan, Noor Sharini Ridzuan, Nor Azliza Ramli, Tan Teck Hong

To Link this Article: http://dx.doi.org/10.6007/IJARBSS/v8-i9/4873

DOI: $\quad 10.6007 /$ IJARBSS/v8-i9/4873

Received: 23 July 2018, Revised: 19 August 2018, Accepted: 06 Sept 2018

Published Online: 14 Sept 2018

In-Text Citation: (Shazali et al., 2018)

To Cite this Article: Shazali, K. H. I., Abu, N. Z., Ruslan, N. L., Ridzuan, N. S., Ramli, N. A., \& Hong, T. T. (2018). The Conceptual Framework between Hygiene and Motivational Factors towards Employees Performance in Joint Force Headquarters of Malaysia Armed Forces. International Journal of Academic Research in Business and Social Sciences, 8(9), 1941-1948.

Copyright: (C) 2018 The Author(s)

Published by Human Resource Management Academic Research Society (www.hrmars.com)

This article is published under the Creative Commons Attribution (CC BY 4.0) license. Anyone may reproduce, distribute, translate and create derivative works of this article (for both commercial and non-commercial purposes), subject to full attribution to the original publication and authors. The full terms of this license may be seen

at: http://creativecommons.org/licences/by/4.0/legalcode

Vol. 8, No. 9, September 2018, Pg. 1941 - 1948

http://hrmars.com/index.php/pages/detail/IJARBSS

JOURNAL HOMEPAGE

Full Terms \& Conditions of access and use can be found at http://hrmars.com/index.php/pages/detail/publication-ethics 


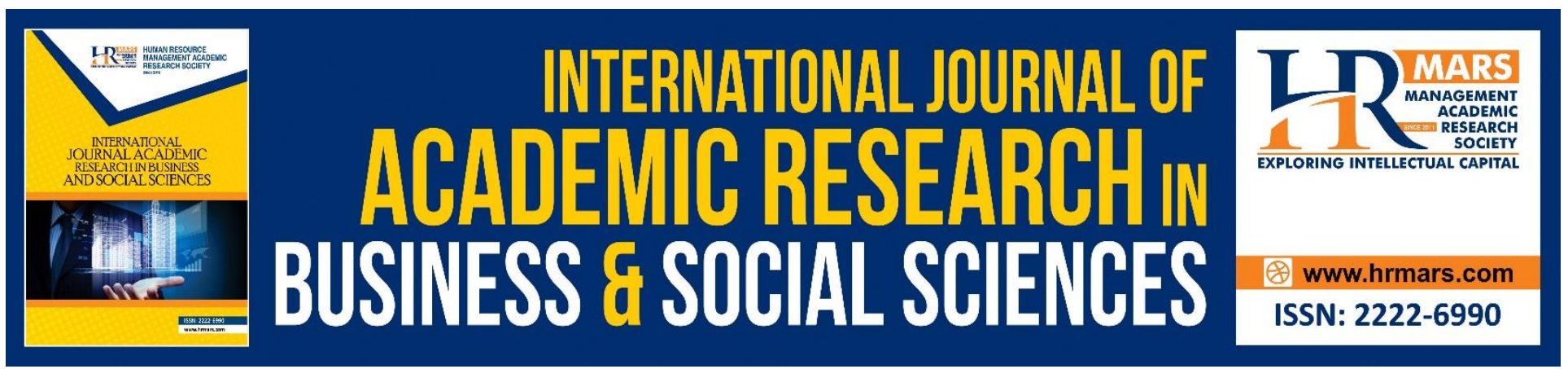

\title{
The Conceptual Framework between Hygiene and Motivational Factors towards Employees Performance in Joint Force Headquarters of Malaysia Armed Forces
}

\author{
Khairatun Hisan Idris Shazali ${ }^{1}$, Nor Zarina Abu², Noor Liyana \\ Ruslan ${ }^{3}$, Noor Sharini Ridzuan4, Nor Azliza Ramli ${ }^{5}$, Tan Teck Hong 6 \\ Faculty of Business and Technology, UNITAR International University, Malaysia
}

\begin{abstract}
The purpose of this study is to propose hygiene and motivation factors in Herzberg's Two-Factor Theory of Motivation as a framework to identify the significant in influencing the employees' job performance in Joint Force Headquarters (JFHQ) or known as Markas Angkatan Tentera Bersama (MK $\mathrm{Ab}$ ) that generally responsible to monitor and handle the assigned forces from two or more services on training, operation and combat support. There are two types of variables used in this research which are Dependent Variables (DV); Job Performance and Independent Variable (IV); Hygiene Factors and Motivator Factors.
\end{abstract}

Keywords: Hygiene Factors, Motivation, Motivator Factors, Job Performance and Joint Force Headquarters (JFHQ).

\section{Introduction}

Motivation is the most imperative elements in influencing human behavior conduct and performance. Consequently, performance of organization is influenced by the degree of motivation imposed on individuals or groups in their work. According to Project Management Institute (2008), the overall success of an organization is influenced by the commitment of each group member derived from group's motivational factors. Performance measurements for any organization are dependent on their primary assets, employees, as well as the ability of the leader to construct a motivated situation among employees. Therefore, it is a challenge for the leader of every department in an organization to keep their employees inspired and satisfied. Hence, all leaders have to be conscious of the needs and requirement of their employees.

Nevertheless, Joint Force Headquarters (JFHQ)or known as Markas Angkatan Tentera Bersama (MK Ab) which consist of few departments also need to keep up the positive working 
environment as mentioned above among the staffs. JFHQ is generally responsible to monitor and handle the assigned forces from two or more services on training, operation and combat support. It is also accountable on the involvement of Malaysian Armed Forces (MAF)in any operation under PBB (Persatuan Bangsa-Bangsa Bersatu) charter. JFHQ staffs come from multiple background, knowledge, experience, skills and seniority. The unique and multi-discipline atmosphere caused and effect and will create some gap in the working environment among the staff. This situation indirectly required the staff immediately change their attitude and mind and as to adapt a new working environment in the organization. JFHQ faces a few issues to execute the joint exercises and joint operational smoothly due to limited staff with knowledge and experience in handling the joint exercises and operation. Factor such as short period of tenure on deployment among the staff is one of the reasons that create the issues. Therefore, JFHQ implement the concept of 'right man for the right job'. However, appropriate job performance still could not be achieved as expected by the higher superior.

The annual report (2014-2016) in JFHQ shows that an increased number of rotations of military posting. Frequent re-posting can create havoc in family life that might affect the workers' job performance. Some exercises need them to deal with other countries that have different doctrines and languages made the exercises not run smoothly. Challenging tasks that include global and international tasks make the staff feel difficulties and have to learn and think out of the box in order to achieve higher command requirement. Even though, every officer and other rank staff have the opportunity to learn new things and gain new experience especially on joint environment, somehow, there are some staffs feel negative due to perform the job that is out of their job expertise. The relationship with peer and superior also plays an important role to make the staffs keen to work. Safety and comfort ambiance might increase the staff's performance. Therefore, this study provides an insight into the factors that influenced job performance in JFHQ which can be valuable to the organization, employees, policymakers, stakeholders and researchers. The research findings offer some implications for the purpose of improvement.

\section{Job Performance}

According to Afshan et al., (2012), performance can be defined as the achievement of specific tasks measured against predetermined or identified standards of accuracy, completeness, cost and speed.

\section{Motivation}

Motivation is derived from the Latin word "movere" meaning "to move' (Tansky, 2003). According to Luthans (1998), motivation is a process that evokes, empowers, leads and maintains behavior and performance. Therefore, it can be considered as the process to increase the desire to perform and accomplish the task. Nevertheless, motivation can be used as a management tool in organization (Sulaiman et al., 2014). Many researchers had developed several major content theories such as Maslow's hierarchy of needs and hygiene and motivator factors by Herzberg to help organization to motivate their employees to be more productive and efficient. According to Shah and Shah (2010), motivation is inspiring people to work; individually or in groups in such a way as to produce best results. 
INTERNATIONAL JOURNAL OF ACADEMIC RESEARCH IN BUSINESS AND SOCIAL SCIENCES

Vol. 8, No. 9, Sept. 2018, E-ISSN: 2222-6990 @ 2018 HRMARS

\section{Relationship between Motivator Factors and Job Performance}

Research has shown significant associations between motivator factors and job performance. Most of the people work to achieve something either it is intrinsic or extrinsic accomplishment. It is important in satisfying people. According to Riley (2005), employee who is able to complete a given work at a predetermined time and receive high reviews result will increase the level of satisfaction and employee motivation. On the other hand, the satisfaction level may be decrease if the individual is unable to finish the project in time or feel rushed and unable to do the job well.

Advancement and opportunities for promotion also encourage job performance. The cycle of advancement, inspiration, satisfaction and feedback are critical to employee performance and worker execution. All parts in this cycle are dependent to each other's. Riley (2005) also mentioned that advancement refers to the predictable or unpredictable possibility of promotion or advancement.

Motivator factors such as 'work itself' and 'growth' can be the factors that can increase the employees job performance. Work itself consist of employees' perception towards their work whether it is too tough or challenging, too relax, tedious and exciting (Riley, 2005). Management that allow and listen to their employees' ideas and give them an opportunity to present, hence gaining the status, responsibility and achieving self-esteem or accomplishing self-acknowledgement, will increase employee's job's satisfaction (Boundless management, 2016). However, if the opportunity for growth is decreasing, or the worker has reached the top, as it is referred to, it will give a bad impact on the satisfaction of the employees who sense and feels their work and position (Riley, 2005).

Another motivator factor is recognition. Brun and Dugas (2008) described recognition as subjective, earnest and genuine feedback based on recognizing people as sincere, deserving of regard, requirement, and equipped with their own ability. Hence, people always want to be recognized, respected and valued for their contribution. According to Harrison (2014), the physical action of doing something to acknowledge and applause for their good effort and work are another aspect of employee recognition. Thus, it will increase the employees' job's performance.

\section{Hygiene Factors}

According to Rowley (1996), the motivation of academic staffs in higher education include the hygiene factors of Herzberg. The authors mentioned about the developing of frustration due to dissatisfaction. Hence, this will prevent workers from doing a good job, punctuality, obsolete equipment, and too many tasks need to be accomplished at the same time. Therefore, the environment needs to alter suit to worker's performance and consistency training is required to ensure productivity. Wiley (1997) said that motivation must be revised as it is very challenging, and an attention need to be given to the workers to enable them to maintain their willingness in doing their job. The workers contribution will lead to employer's redesign jobs, increase pay, change the working environment, or given credits for the work done. However, according to Wessler (1984), managers avoid the assumption that what motivates them will motivate their workers as well.

\section{Relationship between Hygiene Factors and Job Performance}

Herzberg (1959) said that hygiene factors such as company policy, work security, money, working condition, relationship with peer and relationship with supervisor, all not consider as motivational 
factors that produce positive satisfaction. However, if those factors do not exist at work, it will lead to dissatisfaction towards the employees.

Riley (2005) discussed on employees' perception on company policies fair or unfair to them while Domenighetti (2000) and Özyaman (2007) explained on work security when the employees act, or behavior is getting worst due to their worry on job losses.

Relationship with supervisor and peer also play an important role in influencing job performance. According to Tyilana (2005), administrative policies, unfavorable supervision, company policy and interpersonal relationships with supervisors led to $60 \%$ of job dissatisfaction. Relationship with peers has been defined as cooperation, support, trust, exchange of information and atmosphere among peers. Lindner (1998) argues that the reinforcing circle of performance is applicable to salary, commitment to superiors and peers and occupational safety, through one of these factors is higher performance set up, resulting in employee satisfaction and producing higher motivation to implement well in the future.

\section{Proposed Conceptual Framework}

Herzberg (1959) Two-Factor Theory was developed by taking into consideration the motivator factors and hygiene factors in motivating the employees to boost up their job performance. Therefore, this theory will be used as a device to explore motivation and employee performance in the Joint Force Headquarters. Therefore, the conceptual framework for this study is shown in Figure 1.

\section{Conclusion}

The objective of this study is to propose Herzberg (1959) Two-Factor Theory as framework to identify any significant of hygiene and motivation factors that influenced the employees' job performance in Joint Force Headquarters (JFHQ).

A further study should be conducted by using JFHQ data to rectify which factors need to be taken into consideration to improve staff performance and efficiency in the organization. 
INTERNATIONAL JOURNAL OF ACADEMIC RESEARCH IN BUSINESS AND SOCIAL SCIENCES Vol. 8, No. 9, Sept. 2018, E-ISSN: 2222-6990 @ 2018 HRMARS

Figure 1: Conceptual Framework

Source: Adapted from Tan and Wheel (2011)

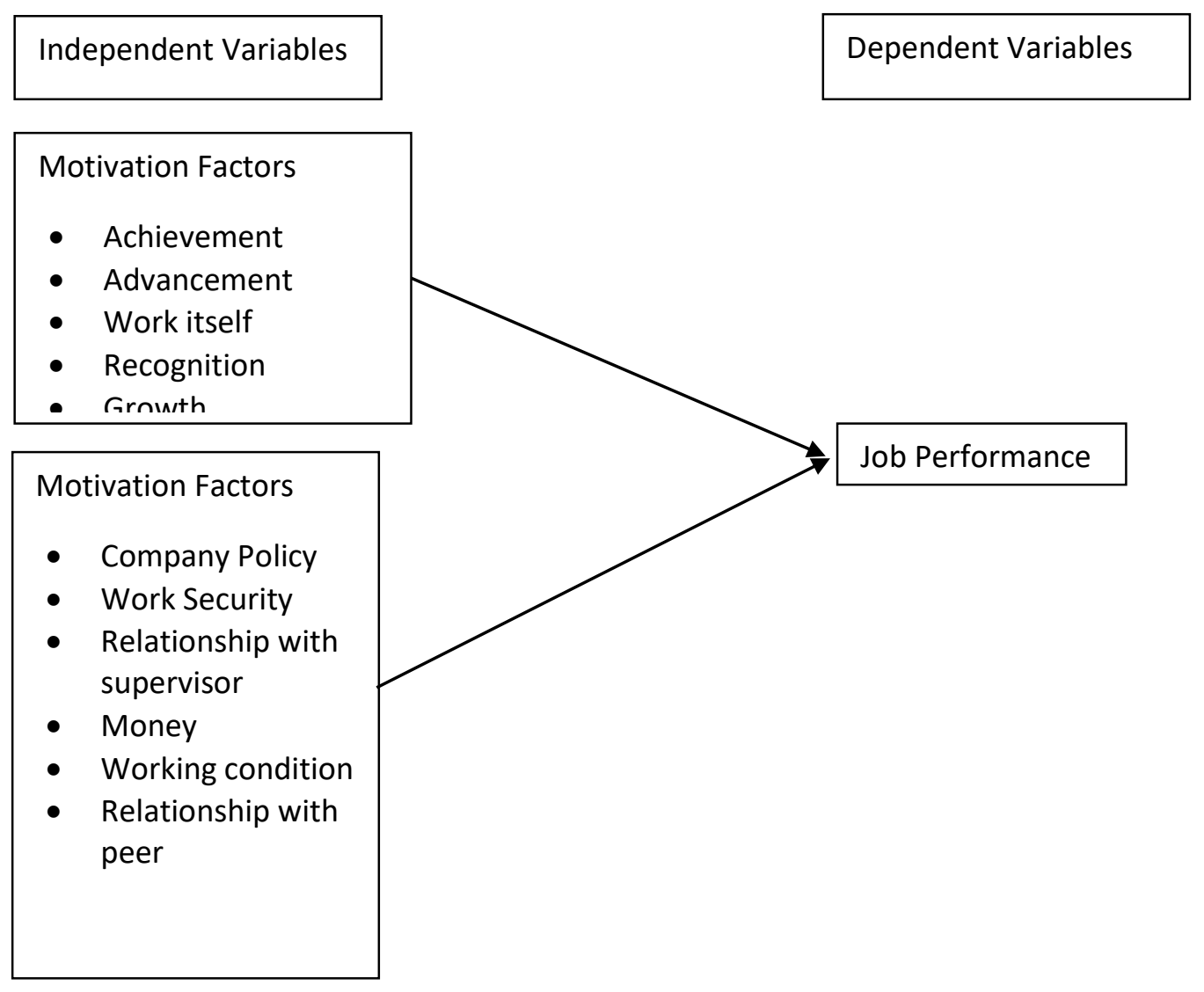


INTERNATIONAL JOURNAL OF ACADEMIC RESEARCH IN BUSINESS AND SOCIAL SCIENCES

Vol. 8, No. 9, Sept. 2018, E-ISSN: 2222-6990 (C) 2018 HRMARS

\section{Corresponding Author}

Khairatun Hisan Idris Shazali

Faculty of Business and Technology

UNITAR International University

Malaysia

Email: khairatun@unitar.my

\section{References}

Afshan, S., Sobia, I., Kamran, A. \& Nasir, M. 2012. Impact of training on employee performance: a study of telecommunication sector in Pakistan. Interdisciplinary Journal of Contemporary Research in Business, 4, 6.

Brun, J.P., \& Dugas, N. (2008). An analysis of employee recognition: Perspectives on human resources practices. The International Journal of Human Resource Management, Vol. 19, No. 4, April 2008, 716-730.

Boundless Management Solution Private Limited (2016). New Delhi, India.

Domenighetti, G., D’Avanzo, B., \& Bisig, B. (2000). Health effects of job insecurity among employees in the Swiss general population. International Journal of Health Services, 30(3), 477-490.

Harrison, K. (2014). Why Employee Recognition is so Important?. Retrieved from https://cuttingedgepr.com.

Herzberg, F., Maunser, B. and Synderman, B. (1959). The Motivation to Work, Wiley, New York, NY.

Imran, A., Ahmad, S., Nisar, A. and Ahamd, U. (2014). Exploring Relationship among Rewards, Recognition and Employees' Job Satisfaction: A Descriptive Study on Libraries in Pakistan. Middle-East Journal of Scientific Research 21 (9).

Joint Force Headquarters. 2014-2016 Annual Report.

Lindner, J.R. (1998). Understanding Employee Motivation. Journal of Extension, 36 (3) ,28-43.

Luthans, F. (1998). Organizational Behavior, Mass: Irwin McGraw-Hill.

Özyaman, F.B. (2007). Hemşirelerde İş Güvencesi Algısı ve Anksiyete ve Depresyon Düzeylerinde Etkisi, (Yayınlanmamış Doktora Tezi), İzmir Dokuz Eylül Üniversitesi Sağlık Bilimleri Enstitüsü.

Project Management Institute (2008). ISBN 978-1-933890-51-7, Fourth Edition. 
INTERNATIONAL JOURNAL OF ACADEMIC RESEARCH IN BUSINESS AND SOCIAL SCIENCES

Vol. 8, No. 9, Sept. 2018, E-ISSN: 2222-6990 (C) 2018 HRMARS

Riley, S. (2005). Herzberg's Two-Factor Theory of Motivation Applied to the Motivational Techniques within Financial Institutions. Senior Honors Theses.

Rowley, J. (1996). Motivation and academic staff in higher education. Quality Assurance in Higher Education, Vol. 4, pp. 11-16.

Selvanathan, M., Selladurai, S., Madina, G., Abdul Rahman, R. and Dawood, N.S.M.S. (2016). Study on Employee's Motivation towards Employee Performance in Private University, Selangor, Malaysia. International Journal of Business and Management, Vol. 11, No. 7.

Shah, K. \& Shah, P.J. (2010). Motivation. Retrieved from http://scribd.com/doc/6564596/motivation (Last access date: November 8th, 2010)

Sulaiman, M., Ahmad, K., BaraaSbaih, B., \& Kamil, M, N. (2014). The perspective of Muslim employees towards motivation and career success. Journal of Social Sciences and Humanities, 9(1), 45-62.

Tansky, J. (2003). Foundations of Management and Human Resources. McGraw Hill.

Tyilana, X. (2005). The Impact of Motivation on Job Satisfaction among Employees of a National Broadcaster. Dissertation Thesis of Master Degree, University of Johannesburg, South Africa. Retrieved from https://elmurobbie.files.wordpress.com/2009/01/the-impact-of-motivationon-job-satisfaction.pdf.

Wessler, R.L. (1984). The psychology of motivation. Marketing Communication, May, pp. 29-32.

Wiley, C. (1997). What motivate employees according to over 40 years of motivation surveys. International Journal of Innovation, Management and Technology, 1(3), 275-78. 